\title{
EFL teachers' practices while teaching reading comprehension in Jordan: Teacher development implications
}

\author{
Naima Al-Husban ${ }^{1}$ \\ ${ }^{1}$ Educational Studies Faculty, Arab Open University, Jordan Tareq, Amman, Jordan \\ ${ }^{1}$ n_husban@aou.edu.jo
}

Received: May 2, 2019;

Accepted: September 25, 2019;

Published: September 29, 2019

\begin{abstract}
This study investigated in-service English as foreign language (EFL) teachers' practices while teaching reading comprehension at schools. Thirty EFL teachers were observed to identify their current practices and teaching quality. To triangulate the trustworthiness of the data, out of those thirty, ten EFL teachers were interviewed. The observation data were analyzed using descriptive statistic particularly frequencies and percent, and the interview data were analyzed using thematic content analysis. The findings of the study revealed that teachers taught students reading comprehension traditionally. Most of the observed and interviewed teachers knew the names of the reading comprehension strategies and the stages of teaching reading comprehension. However, they did not know how to employ and practice them. Based on the results, it is necessary to design professional development programs to empower EFL teachers on how to present these strategies and to conduct further research on this topic while considering other variables, like experience and the nature of curricula.
\end{abstract}

Keywords: in-service EFL teachers; reading comprehension; stage reading instruction; comparative education; adult education

How to cite this paper (in APA style): Al-Husban, N. (2019). EFL teachers' practices while teaching reading comprehension in Jordan: Teacher development implications. Journal on English as a Foreign Language, 9(2), 127-145. doi:http://dx.doi.org/10.23971/jefl.v9i2.1288

DOI: http://dx.doi.org/10.23971/jefl.v9i2.1288

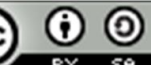

Journal on English as a Foreign Language, 9(2), 127-145

Copyright @ 2019 by JEFL, p-ISSN 2088-1657; e-ISSN 2502-6615 
Living in the age of technology and globalization makes life easier in all respects, and machines play most of the human beings' roles, but reading comprehension requires that readers process and interact with a text to understand it (Ness, 2009; Rublik, 2017; Sofiana, 2018). Therefore, reading skills are important not only in languages but in all school subjects; therefore, the ultimate goal of any subject is to help learners understand it (González, 2017).

Currently, reading researchers and scholars mainly focus on helping readers to understand and comprehend written texts. That is, they consider reading comprehension as an active process and it consists of several tasks that readers should perform to understand the written texts, and these tasks and steps should be taught to students (Ness, 2009; Priajana, 2015; Li \& Clariana, 2019). In this vein, Rublik (2017) deemed the reading process to be not only a matter of extracting information from the text but an active process through which learners retrieve their previous knowledge from their minds as well as refining this knowledge with the new information they read in the text. In turn, González (2017) revealed the importance of reading comprehension to help learners become successful members at school and in society. It is also necessary to be effective learners; that is, educational success requires successful readers.

It is of paramount significance to highlight the idea that Ness (2009) and Ngabut (2015) described, top-down model of reading in which the learner brings knowledge, expectations, and questions to the text and they continue reading if the text meets their expectations. In other words, learners' schemata play a major role in comprehending the text, which is one of the main notions of constructivism. Additionally, the social constructivist nature of comprehension proposes that learners improve their understanding by negotiating to mean with others. This takes place through discussion. Participating learners in discussion enhance active engagement in building meaning from a text. The social nature of construction reflects the principle of social mediation of Vygotsky's (Mckeown, Beck, \& Blake, 2009). This leads to an explanation of the relationship of reading comprehension with schemata theory, which reveals the importance of activating prior knowledge by teachers implementing various strategies, like visual clues, predictions, questioning, or summarizing.

The idea of schemata theory means that reading comprehension does not improve in a vacuum, but instead needs teachers who are well equipped with the instructional strategies that have been proven by research to improve learners' achievement. According to McLaughlin (2012), teachers play an important role in the reading process by creating an appropriate atmosphere to 
engage learners with the text, and this requires teachers to employ an effective way of instructing by including some research-based instructional strategies that foster readers' reasoning, like previewing, questioning, taking notes, and evaluating. This explains why reading comprehension instruction is deemed a key competence for every teacher, so researchers should focus on changing the stereotype idea that learners comprehend texts spontaneously and do not need any help. On the contrary, teachers should exert much effort in reading comprehension instruction and learn research-based instructional strategies, like prediction and retrieving previous knowledge to engage learners with the information in the texts (Al-husban \& Alkhawaldeh, 2016).

Similarly, Pardo (2004) stated that teachers help learners be good readers by activating their prior knowledge so that they can easily understand the information in the text. Teachers can help learners build this knowledge if they do not have it. Teachers also help learners build their knowledge by creating concept maps to identify the relationship between the concepts in the text and their previous ones. Additionally, teachers present the vocabulary necessary to understand the reading text and motivate learners by using authentic texts or tasks.

Furthermore, according to Gilakjani \& Sabouri (2016), teachers help learners think critically and monitor their comprehension if teachers employ various instructional strategies while teaching reading. This reveals the importance of teachers' familiarity with reading instructional strategies and employing them in their teaching classroom. To employ these strategies, teachers need to be trained on how to employ them in the classroom. For decades, researchers have argued that teachers are not expected to be able to teach reading comprehension without having been trained to do so, like Ngabut (2015), who explained that language teachers should be trained to help learners in reading comprehension, one of the most complicated skills.

After several years, this is still an urgent need. Pressley (2001), Klapwijk (2012), Noor (2016), and Sofiana (2018) stated that teachers in their study had limited resources of instructional strategies while teaching reading comprehension. However, having a repertoire of instructional strategies is of importance for teachers to help students deal with reading passages and making meaning. There is no clear vision of how teachers presented reading comprehension due to the negligence of professional development programs in this area of instruction (Pressley, 2001). Similarly, Manoli and Papadopoulou (2013) showed that there is a lack of reading comprehension strategy instruction and teachers in their study were not involved in teaching students how to 
approach and comprehend English language skills; they also revealed the teachers' practices were mainly reading aloud and teaching vocabulary.

The research revealed the importance of developing teacher professionally in leveraging their performance in teaching reading skills like Takallou (2011) who examined the effect of teaching learners reading comprehension using research-based strategies, such as, metacognitive awareness, planning, exploiting their prior knowledge. Similarly, Ness (2009) and Sofiana (2018) stated that learners' performance in reading comprehension has increased due to implementing reading comprehension strategies like activating prior knowledge, previewing, and asking questions. This needs teachers who are well-equipped with these strategies to be able to employ them in the classroom.

In this vein, several studies were also conducted to identify teachers' practices while teaching reading comprehension. For example, Manoli and Papadopoulou (2013) studied Greek EFL teachers' reading comprehension practices; the authors observed five teachers and collected data through interviews and observations. The results showed that teachers mainly focused on oral reading, teaching vocabulary, and asking questions, demonstrating that there was a lack of research-based reading comprehension instruction. This lack means that teachers did not help students understand the reading texts. Authors recommended that further research should be conducted to verify the finding of the study.

Furthermore, Dole (2000) as cited in Ortlieb (2013) states through her observations of teachers that for a long time teachers' main role was to ask students questions about the reading passages and ask them to identify the main ideas, then teachers identified if learners' responses were right or wrong. In the same context, Enyew and Yigzaw (2016) observed four English language classes three times to identify the teachers' practices while teaching reading comprehension. They collected data using observation checklists and interview. The authors found that the observed teachers did not employ any of the effective reading comprehension practices proven by the body of research. Ness (2009) also observed 2400 minutes of direct classroom observation; only about 82 minutes (3\%) of the total was reading comprehension instruction. The study revealed that teachers did not feel qualified for teaching reading comprehension explicitly.

Similarly, Ong (2016) conducted a study to explore teachers' practices while teaching reading comprehension using interview and classroom 
observation. The author found teachers in Cambodia were not familiar with proven instructional strategies while teaching reading comprehension and they tended to employ traditional teachers centered approaches in reading classes that focused on rote memorization.

The previous research finding showed the importance of investigating teachers' practices during their teaching of reading comprehension to diagnose the status and then identify the training needs of teachers in this important area. This issue restates what Durkin argued as cited in Ortlieb (2013), teachers did not help learners comprehend the reading passages as they just tested learners rather than teaching them reading comprehension. For example, one of her observed teachers mentioned the strategy of identifying the main ideas in the text, and then tested if the learner could identify the main idea. If the learner could not do the task, the teacher moved to another learner. This is not teaching, teachers should show learners how to perform the task or the strategy.

The situation in Jordan is not so different from the international one. According to Al-jamal, Al-hawamleh, and Al-jamal (2013), and Al-husban and Alkhawaldeh (2016), EFL learners in Jordan faced obstacles in understanding reading texts, so they relied on memorizing reading passages and questions to pass the exams due to the limited performance in teaching reading skills as they focused on asking factual questions and the meaning of difficult words. Similarly, the Phenix Center for Economics and Informatics Studies in 2014 found $22 \%$ of Jordanian students in basic grades could not read the Arabic or English languages due to the ineffective instructional strategies that teachers employed while teaching reading comprehension.

This unveils the importance of studying thoroughly the everyday practices of teachers, which shine a light on their weaknesses and design training programs. In the same vein, Alhabahba, Pandian, and Mahfoodh (2016) stated that EFL teachers faced several challenges while teaching reading comprehension due to the limited resources and the necessary training in how to teach reading comprehension; therefore, most teachers followed teachercentered approaches and grammar-translation approaches. Until now, Asassfeh (2013), Freahat and Al-Faoury (2015), and Alhabahba et al. (2016) all concurred that teaching reading comprehension did not empower EFL learners to be strategic readers especially when they enrolled higher education. As a result, those learners had negative attitudes towards learning the English language.

In Jordan, there were several studies that investigated teachers' current practices, like Al-husban and Alkhawaldeh (2016), Phenix Center for Economics 
and Informatics Studies (PCEIS) (2014), Qarout et al. (2015), Phenix Center for Economics and Informatics Studies (PCEIS)(2014), and Smadi and Al-Shraa'h (2015) who all conducted national surveys to identify the current practices of teachers especially EFL teachers. They all tried to investigate the performance of teachers and their classroom practices. They found teachers know the names of most of the reading comprehension strategies. However, their teaching performance was not satisfactory.

It is essential to mention that questionnaires were the main research tool used by most studies; that is, authentic data were not obtained to identify how teachers employ reading comprehension instruction. Therefore, the current study tried to collect authentic data using observation. According to Cohen et al. (2018), observation as an essential research tool has the potential to yield more valid and authentic data than would other research tools; observation is strong on face validity and non-linguistics, and it provides valuable contextual information, and collects all kinds of data linguistics and non-linguistics. Additionally, Cohen et al. (2018) stated that observation provides reality checks and help investigators differentiate between what is said and done.

All in all, this study endeavored to describe real-world classroom instruction, what reading comprehension strategies EFL Jordanian teachers in the primary stage employed and inform educators about possible ways to embed effective practices while teaching reading comprehension. This study is also a mixed study design, using a case study from fifteen schools as a research design. It was conducted to investigate the current practices of EFL teachers in Jordan during their teaching of reading comprehension. Thus, the study aimed to address the following research questions, "Which reading strategies did observe EFL teachers employ while teaching reading comprehension?, and how did EFL teachers implement these strategies?"

The current study investigates EFL teachers' practices while teaching reading comprehension, so it tries to shed more light on the significant role of teachers' practices in improving their teaching performance, and engaging students while teaching this skill. Moreover, the findings of this study are important for decision-makers to design the necessary professional development programs on how to employ the most effective reading comprehension strategies. The results of this study may have practical implications for principles and EFL supervisors on how to assess EFL teachers' performance while teaching reading comprehension. 


\section{METHOD}

\section{Participants}

The participants of the study were thirty Jordanian EFL teachers. They were observed in their classrooms before enrolling in an in-service program at Arab Open University including a course related to teaching English as a foreign language (TEFL) to investigate what EFL teacher already knew about reading comprehension instruction. The teachers were EFL teachers who had a bachelor's degree in English literature and taught the primary stage from the first grade to tenth grade.

The sampling approach was a purposefully chosen sampling, as the teachers started an in-service training program in the academic year 2018-2019 at Arab Open University- Jordan, and it is useful to identify their current practices and their quality prior to taking the (TEFL) course to identify their accurate needs related to teaching English as a foreign language.

\section{Research Instruments}

Two research instruments were implemented, semi-structured interview and structured observation. It is common for researchers to collect data related to classroom practices using questionnaires, but due to the nature of the research topic, classroom observation provides first-hand and live data, in its natural setting (Ong, 2016; Cohen et al., 2018). Similarly, Farrell and Bennis (2013) stated the importance of using classroom observation due to the dominance of using questionnaires at the expense of using observation. Rahman, Singh, and Pandian (2018) also mentioned that few researchers endeavored using observation to identify teachers' practices, so it is one of the best research tools for achieving the objectives of the current study.

\section{Data Collection Procedures}

Data were collected during four-week visits to the target schools, through these visits, structured observations were conducted to collect specific types of information to answer the study's questions and to identify the interactions in the classroom without influencing them. After getting the approval of the teachers to participate in the study, they were asked to choose four reading comprehension lessons to be observed by their own choice. Each reading comprehension classroom observation lasted for 45 minutes for the case study at the school. The classroom observation aimed to explain to the 
participants of the study which was to identify reading comprehension strategies EFL teachers employed before during and in the post-reading classes.

A classroom observation checklist was designed based on the literature review of the research-based practices EFL teachers could do in the different stages of teaching a lesson, the observation was conducted by the researcher and a co- rater an EFL supervisor to ensure the validity of the observation process, then agreement coefficient was calculated.

Ten EFL teachers were interviewed using semi-structured Interview after the fourth structured observation, then recorded in a written form, transcribed, and crosschecked with the participants of the study to establish the validity of the study, then coded into the main two themes: which practices they employed, and how they employed them.

Regarding the validity of the research tools, a jury of experts reviewed both research tools, and their comments were taken into consideration. Both research tools have been conducted on a pilot sample to identify their appropriateness and clarity. To ensure reliability, inter-rater reliability coefficient was calculated according to the number of agreements between two coders, it was (0.91), acceptable for this study.

\section{Data Analysis Procedures}

This study is a real-world discovery study; it enabled the investigator to access interactions in social contexts, yielded systematic records of these interactions, and complemented other types of data. Therefore, it led to a thorough understanding of the research problem. The researcher applied structured observation as well as interviews to collect data.

Structured observation enabled the researchers to produce numerical data like frequencies and percent, which, in turn, assisted in comparing things and situations and formulating frequencies, patterns, and inferences and interpretations. Therefore, the researcher and the co-rater identified the frequencies of each item in the rating scale, then percent were calculated, the descriptive statistic provided certain insights and implications in which practices EFL teachers usually perform and they were familiar with. The structured observation was useful in this study to focus on exactly what EFL teachers did during teaching reading comprehension to assist in understanding how EFL teacher presented this important skill. 
The analysis of the interview was done by the researcher and the co-rater by transcribing the ten interviewees' responses, categorized responses, then analyzed by grouping interviewees' responses according to the use of effective instructional practices while teaching reading comprehension, and how they employed them. Data of the interview were useful to answer the research questions and to clarify and support the observation findings.

\section{Context}

This study was conducted during the first semester of the academic year 2018/2019 on thirty EFL teachers in different schools chosen to participate in this study. The English language has been the foreign language taught in Jordan since 1946 starting at the age of eleven - fifth grade. However, since the 1990s, English has been taught from the first grade until twelfth grade.

Jordan is a developing country and in spite of its limited resources, it tries to leverage the students' level in the English language by adopting good professional training programs and training teachers to be excellent in their profession. However, due to a large number of teachers, and students especially after the Syrian crisis after 2011, the teaching-learning process deteriorated (Phenix Center for Economics and informatics Studies, 2014). The schools, in which teachers were observed, were chosen according to the willingness of EFL teachers to be observed and to participate in the current study. Every EFL teacher was observed four times over two months in reading comprehension classes according to a specific schedule agreed on with the observed teachers. There was a co-rater to ensure the reliability of the data.

\section{FINDINGS}

Based on the research study questions, data collection and analysis were performed. The analysis was initiated from teachers' classroom observations and semi-structured interviews. The data collected by the research tools were categorized, analyzed and interpreted. Then, data of each research question was presented, and then the findings of related research studies that consolidated the findings of the current study were demonstrated.

To answer the first question, "which reading strategies did observe EFL teachers employ while teaching reading comprehension?", the structured observations were conducted, and the Table 1 showed the frequencies and the

percent of the reading comprehension practices observed EFL teachers revealed.

Journal on English as a Foreign Language, 9(2), 127-145

Copyright @ 2019 by JEFL, p-ISSN 2088-1657; e-ISSN 2502-6615 
Table 1. EFL teachers' observed practices of reading comprehension strategies

\begin{tabular}{|c|c|c|c|}
\hline No & $\begin{array}{c}\text { Reading comprehension strategies and } \\
\text { practices }\end{array}$ & Frequencies & $\begin{array}{c}\text { Percentages } \\
(\%)\end{array}$ \\
\hline 1 & Set specific learning objectives & 16 & 53.3 \\
\hline 2 & $\begin{array}{l}\text { During the pre-reading lesson, Previewing } \\
\text { the text by focusing on the title and the } \\
\text { illustration }\end{array}$ & 16 & 53.3 \\
\hline 3 & $\begin{array}{l}\text { During the pre-reading lesson, using } \\
\text { prediction to activate learners' prior } \\
\text { knowledge }\end{array}$ & 13 & 43.3 \\
\hline 4 & $\begin{array}{l}\text { During the pre-reading lesson, generating } \\
\text { discussion to motivate learners to read the } \\
\text { text. }\end{array}$ & 12 & 40 \\
\hline 5 & $\begin{array}{l}\text { During the pre-reading lesson, presenting } \\
\text { new words that were necessary to } \\
\text { understand the reading text. }\end{array}$ & 28 & 93.3 \\
\hline 6 & $\begin{array}{l}\text { During the reading lesson stage, evaluating } \\
\text { learners' predictions. }\end{array}$ & 13 & 43.3 \\
\hline 7 & $\begin{array}{l}\text { During the reading lesson stage, factual } \\
\text { questions were asked by the teacher }\end{array}$ & 29 & 96.6 \\
\hline 8 & $\begin{array}{l}\text { During the reading lesson stage, higher } \\
\text { thinking level questions were asked by the } \\
\text { teacher }\end{array}$ & 3 & 10 \\
\hline 9 & $\begin{array}{l}\text { During the reading lesson stage, learners } \\
\text { were encouraged to use keywords while } \\
\text { discussing or answering questions. }\end{array}$ & 10 & 33.3 \\
\hline 10 & $\begin{array}{l}\text { During the reading lesson stage, explaining } \\
\text { the text structure while monitoring } \\
\text { learners. }\end{array}$ & 27 & 90 \\
\hline 11 & $\begin{array}{l}\text { During the post-reading lesson stage, } \\
\text { learners were asked to summarize the text }\end{array}$ & 23 & 76.6 \\
\hline 12 & $\begin{array}{l}\text { During the post-reading lesson stage, } \\
\text { learners were encouraged to explain their } \\
\text { opinions towards the reading topic and } \\
\text { their critical judgments. }\end{array}$ & 3 & 10 \\
\hline 13 & $\begin{array}{l}\text { During the reading lesson stage, the } \\
\text { teachers monitored learners' } \\
\text { comprehension and provided learners with } \\
\text { feedback. }\end{array}$ & 5 & 16.6 \\
\hline 14 & $\begin{array}{l}\text { Cooperative learning was used regularly } \\
\text { by the teacher }\end{array}$ & 15 & 50 \\
\hline
\end{tabular}




\begin{tabular}{llll}
\hline 15 & $\begin{array}{l}\text { The teacher provided an explicit } \\
\text { explanation of the required reading } \\
\text { comprehension skills }\end{array}$ & 0 & 0 \\
$16 \quad \begin{array}{l}\text { The teacher informed learners what to do } \\
\text { at each stage of the reading lesson. }\end{array}$ & 2 & 6.6 \\
\hline
\end{tabular}

Table 1 shows the frequencies and the percent of occurrence of practices of teaching reading comprehension identified while being observed. It unveils that most observed teachers focused mainly on asking factual questions rather than higher thinking questions. Additionally, most observed teachers revealed their interest in presenting new words that are necessary to understand the reading text, and explaining the structures of the text while monitoring learners, their percent of frequency were respectively (96.6\%, 93.3\%, and 90\%). The results also showed mediocre frequencies of practicing strategies like setting learning objectives, previewing, activating prior knowledge, presenting new words, and summarizing.

On the other hand, the results uncovered that few of the observed teachers evaluated their learners' predictions $(43.3 \%)$, asked their learners to explain their opinions $(10 \%)$, or provided feedback to their learners $(16.6 \%)$. Additionally, none of them gave an explicit demonstration of the reading comprehension strategies or even told learners what to do in each stage (pre, during, or post). It can be said that teachers showed almost similar practices while teaching reading comprehension lessons after observing four classes for each EFL teacher. Most observed teachers had limited familiarity with the strategies that they had to employ while teaching reading comprehension. Moreover, the comprehensive way of using the strategies that reflected highlevel of thinking was used at a less than mediocre level like points $(8,6,12,13$, 15 , and 16).

To answer the second question, "How did EFL teachers implement these strategies?", ten EFL teachers were interviewed after being observed to clarify more what they have presented during observing the reading comprehension classes. Semi-structured interviews with ten participants were conducted which focused on how participants employed the reading comprehension practices and strategies. There were two main questions to clarify the way of using reading strategies while teaching, namely, what are the strategies/practices you use while teaching reading comprehension? how do you implement these strategies? The findings of the interview are as follows. Most participants reported that during the pre-reading comprehension stage they stated the 
learning objectives of the lessons, presenting new words to help students understand the reading texts, except a participant who said that "Students need practice reading aloud, understand the structures of the text, they do not understand the objectives of the lesson, they are for the teacher".

Most EFL teachers stated that during the reading comprehension class they asked students to read the text, some of them said to read aloud and some of them said to read silently, then they directed students to answer the questions, check them, and then explain the structures and grammatical rules including in the reading text. A participant said that "My students read the text aloud, answer questions, then I asked them to underline all the verbs, and I deeply explained to them the main tense used in the text".

Another teacher said that "In the reading task stage teachers divide the text into few parts (two or three) and give each part with the related task to one student or a group of students for a limited time. After that, the teachers Compare the student's answers and discuss the answers with the students"

Most teachers said that during the post-stage of teaching reading comprehension, they gave students homework, students who didn't read aloud, took their turn, and read. Another teacher said that "make general discussions about the text content, summarizing text, reviewing texts and giving the student reading homework."

Most teachers reported that they gave students homework, corrected mistakes, told students to do exercises in the textbook, and provided student's feedback in the post-stage reading comprehension. For example, "I do reading comprehension exercises in pupils' books with students.", "I ask students to summarize the text", "I try to correct students' mistakes in pronouncing new words or while reading."

In teachers' answers for the question of how they implement these strategies, most teachers reported that they asked students to guess the meaning of the new word, to identify the tenses of the words, to read aloud, and to answer questions after reading. One of the participants said that, "I start reading each paragraph, explain new vocabulary, students describe pupils' book pictures, I write meanings of words in native language on the board, students take turns reading each paragraph, as I explain new words and ideas, I ask questions about each paragraph, revised the whole text via $Q \mathcal{E} A$, then I corrected the mistakes of teachers and provided them feedback" 
Another teacher said that "I use pictures to introduce the topic of reading, then students read the text silently, I write the questions on the board, then I ask students to answer them, then I explain new words in native language". Other teachers reported her way of teaching by saying that, "I introduce the topic of reading by reading the title, and ask them what they know about it, then students read aloud the text, I explain any new words while students reading aloud, then I explained the grammatical rules and I ask students to read again to identify examples of these rules, and I corrected mistakes and provided feedback."

It can be summarized that EFL teachers revealed slightly different practices and strategies that they used while teaching reading comprehension. All the teachers tended to state the lesson objectives and introduce the topic. Some of them elicited prior knowledge, and asked and answered questions, presented grammatical rules, and explained new necessary words that help students to understand the text. Most of these practices were consistent with the data collected through observation, for example, focusing on factual questions and explaining new words and structures.

Some teachers said they asked students to read either aloud or silently without showing why they asked students to do so. Some teachers mentioned they provided feedback, corrected mistakes, or monitored students; these showed teachers could not differentiate between the three terms. Some teachers asked students the questions after reading, thereby students read and they didn't know why they are reading. All teachers think that teaching comprehension is a matter of teaching new words and structures

Furthermore, some observed teachers could differentiate between the three stages "pre, during, and post stages" of reading lessons. Some said what they did exactly during teaching reading comprehension without stating the stages, 1. It seemed that teachers said what they knew and regularly did in the classroom, and this explained what was observed: those teachers just name the strategy or ask students to do the task. For example, the teachers said to summarize without showing students how to perform it. Asking questions was a prominent strategy and practice; most teachers said they asked their students questions about the reading texts. However, according to the observation results, most questions were asked on the literal level: What is the main idea? What did the man do in the story? How many children does the man have? In the interview, it can be inferred that questions were also literal due to saying simple questions or using the questions in the textbook.

Journal on English as a Foreign Language, 9(2), 127-145

Copyright @ 2019 by JEFL, p-ISSN 2088-1657; e-ISSN 2502-6615 


\section{DISCUSSION}

When analyzing EFL teacher's practices while teaching reading comprehension using two research tools to make comparisons and see whether teachers are aware of their practices and how to employ them meaningfully, it is necessary to triangulate all data collected as a way of testing the trustworthiness of the data.

The first research question examined EFL teachers' practices and strategies while teaching reading comprehension. Results revealed that the frequencies of some of the reading strategies were very in a middle rate like setting goals, previewing to predict the content of reading and evaluating reading, generating discussions to motivate students to read, and providing feedback. This reveals teachers acquired knowledge about what the reading comprehension strategies are, but due to having limited practice or training, they avoid employing them, and this is in line with Al-husban and Alkhawaldeh (2016) and Ong (2016).

The frequency of some of the other practices are not up to the mark; that is, observing thirty EFL teachers for four classes to identify if they practice the sixteen reading comprehension strategies, results showed that observation data and the data of interviewing revealed that EFL teachers had limited, traditional and superficial understanding of the reading comprehension strategies and practices. They did not know the importance of each stage and the specific procedures should be performed in each stage, for example, in the pre-stage reading: teachers should identify the outcomes, present the topic, engage students in discussion about the topic of reading, presenting new words, then clarifying the tasks to be performed and how to be performed by modeling it like scanning, skimming, and prediction.

Findings also indicated that the participants of the study were unaware of how to move from each stage to another smoothly, what or how to teach learners at each stage; they were just asking questions like "what is the meaning of pollution?" or teachers asked students to identify the main ideas, or summarize the text, without applying these practices and strategies, and why they should apply them, such as asking learners to summarize the main ideas of the text, so it is necessary to show learners how to summarize the main ideas in the text by modeling it.

This idea is in line with what Durkin clarified as cited in Ortlieb (2013) and Talebi and Marzban (2015), that teachers did not teach learners how to 
process the reading text and apply the reading comprehension strategies but instead asked them questions, without modeling the strategy. Rublik (2017) stated that, according to Vygotsky's theory, to help learners become independent, they need assistance and guidance from an adult, and in this context, the teacher is the assistance by showing students how to preview, predict, scan, skim, guess the meaning of new words, summarize, and interact with his her group.

Regarding the second question, "How do EFL teachers implement reading comprehension?", the analysis of the observation data showed that teachers asked students to employ limited reading comprehension strategies, like reading either aloud or silently, answer questions, identify examples of structures and summarizing. However, they didn't use the effective reading strategies that research findings recommended EFL teachers to employ like previewing, taking notes, answering critical thinking questions. Moreover, teachers did not show students how to employ the strategies and practices if they ask students to predict or summarize, it was a kind of testing rather than teaching reading comprehension. This explained the deteriorated level of students in reading comprehension in Jordan.

These results are in line with the results of studies like Smadi and Alshra'ah (2015) and Amoush (2012). Jordanian EFL learners suffer in determining the appropriate reading comprehension strategy they should use and how to employ it because their teacher did not show them how to use it. This could raise another challenge which is the quality of professional development programs Jordanian EFL teachers are exposed to. Smadi and AlShra'ah (2015) stated that pre-service training programs are limited to teachers who teach learners from kindergarten (KG) to third grade whereas teachers who came from other subject faculties did not receive any pre-service training. Moreover, in-service training programs are also limited, and there is no systematic framework for training teachers by the Ministry of Education except some institutions that trained a specific number of teachers.

In this sense, EFL teachers in Jordan need to be exposed to professional development programs that have practical aspects in which EFL teachers become familiar with these effective practices while teaching reading comprehension, and how to employ and model them to transfer these strategies to students. It is not just applied for the Jordanian context; it is an international situation regarding teachers of the English language while teaching reading comprehension. Besides, there is a common assumption that reading is a selfgrowing skill and there is no need to exert much attention to it, thereby teacher 
development in this issue is not comprehensive and do not focus on developing teachers' skills and practices to be applied while teaching reading comprehension.

\section{CONCLUSION}

The current study, in which EFL teachers were observed and interviewed to identify their actual practices while teaching reading comprehension, revealed that teachers tested students and used few of reading comprehension strategies on a mediocre level, and they could not apply most of the reading comprehension strategies, they just know their names. Based on the results of the study, EFL teachers have to help the learner to reach excellence in their teaching, rather than only saying terms and not employing them properly. EFL teachers should acquire practical knowledge about how to teach reading comprehension, and it should be reflected in their performance and everyday practices by providing them with professional development training programs. Additionally, further research should be conducted in this field in different contexts and conditions.

\section{REFERENCES}

Al-husban, N. A., \& Alkhawaldeh, A. (2016). Exploring English as a foreign language (EFL) female teachers ' knowledge of Marzano 's researchbased instructional strategies and its relationship with their level of performance in teaching reading comprehension at the educational directorate of Zarqa. Dirasat-Educational Science Journal, 5( 43), 2195-2207.

Al-jamal, D., Al-hawamleh, M., \& Al-jamal, G. (2013). An assessment of reading comprehension practice in Jordan. Jordan Journal of Educational Sciences, 9(3), 335-344.

Alhabahba, M. M., Pandian, A., \& Mahfoodh, O. H. A. (2016). English language education in Jordan: Some recent trends and challenges. Cogent Education, 3(1), 1-14. https://doi.org/10.1080/2331186X.2016.1156809

Asassfeh, S. M. (2013). Prospective EFL teachers: What language learning beliefs do they hold? Asia-Pacific Education Researcher, 24(1), 13-26. https: //doi.org/10.1007/s40299-013-0154-1

Cohen, L. Manion, L., \& Morrison, K. (2018). Research methods in education (8th ed.). London: Routledge

Dole, J. A., (2002). Comprehension strategies. Literacy in America: An Encyclopedia of History, Theory, and Practice, 1(1), 85-88.

Enyew, C., \& Yigzaw, A. (2016). Teacher's current practices of teaching reading and grade four students' reading achievement in Dona Berber primary 
school. Science, Technology and Arts Research Journal, 4(3), 265-276. https://doi.org/10.4314/star.v4i3.38

Farrell, T. S. C., \& Bennis, K. (2013). Reflecting on ESL teacher beliefs and classroom practices: A case study. RELC Journal, 44(2), 163-176. https://doi.org/10.1177/0033688213488463

Freahat, N. M., \& Al-Faoury, O. H. (2015). Reading passages and skills in Jordanian high school and university EFL textbooks: A comparative analytical study. Theory and Practice in Language Studies, 5(1), 16. https://doi.org/10.17507/tpls.0501.03

Gilakjani, A. P, \& Sabouri, N. B. (2016). How can students improve their reading comprehension skill? Journal of Studies in Education, 6(2), 229. https://doi.org/10.5296/jse.v6i2.9201

González, A. M. G. (2017). Reading comprehension in an English as a foreign language setting: teaching strategies for sixth-graders based on the interactive model of reading. Folios, 45(1), 159-175. https://doi.org/10.17227 01234870.45folios159.175

Henk, W. A., Marinak, B. A., Tomasetti, B. W., \& Moore, J. C. (2000). A reading lesson observation framework for elementary teachers, principals, and literacy supervisors. Reading Teacher, 53(5), 358-369.

Klapwijk, N. M. (2012). Reading strategy instruction and teacher change: Implications for teacher training. South African Journal of Education, 32(2), 191-204. https://doi.org/10.15700/saje.v32n2a618

Li, P., \& Clariana, R. B. (2019). Reading comprehension in L1 and L2: An integrative approach. Journal of Neurolinguistics, 50 (1), 94-105. https://doi.org/10.1016/j.jneuroling.2018.03.005

Manoli, P. \& Papadopoulou, M. (2014). Reading Comprehension practices in Greek elementary EFL classrooms 1. Cefr, 1, 1-22.

Mckeown, M. G., Beck, I. L., \& Blake, R. G. K. (2009). Rethinking reading comprehension. Reading Research Quarterly, 44(3), 218-253. https://doi.org/dx.doi.org/10.1598/RRQ.44.3.1

McLaughlin, M. (2012). Reading comprehension: What every teacher needs to know. Reading Teacher, 65(7), 432-440. https://doi.org/10.1002/TRTR.01064

Ness, M. K. (2009). Reading comprehension strategies in secondary content area classrooms: Teacher use of and attitudes towards reading comprehension instruction. Reading Horizons, 49(2), 143-166. https: //doi.org/10.1080/02568543.2010.531076

Ngabut, M. N. (2015). Reading theories and reading comprehension. Journal on English as a Foreign Language, 5(1), 25-36.

Noor, H. M. (2016). Second language reading comprehension strategies in Brunei 
Darussalam's primary schools. Unpublished Doctoral Dissertation. Queensland: The University of Queensland.

Ong, B. (2016). Understanding and practice of teaching reading in content areas in upper elementary classes in Suburban public schools in Cambodia. ProQuest Dissertations and Theses, 303. Retrieved from https:/Aspace.library.utoronto.ca/bitstream/1807/76576/B/Ong_Bopha_20 1611_PhD_thesis.pdf

Ortlieb, E. (2013). Using anticipatory reading guides to improve elementary students' comprehension. International Journal of Instruction, 6(2), 145-162.

Pardo, L. S. (2004). What every teacher needs to know about comprehension. The Reading Teacher, 58(3), 272-280. https://doi.org/10.1598/rt.58.3.5

Phenix Center for Economics and Informatics Studies (PCEIS). (2014). Improving the quality of primary public education in Jordan. 1-6. Retrieved from http://www.phenixcenter.net/uploads/en_phenixcenter.net_63544042145 6559882.pdf

Pressley, M. (2001). Comprehension instruction: What makes sense now, what might make sense soon. Reading Online, 5(2).

Priajana, N. (2015). Student teachers' reading habits and preferences. Journal on English as a Foreign Language, 3(2), 71-76. https://doi.org/10.23971/jefl.v3i2.65

Rahman, M. M., Singh, M. K. M., \& Pandian, A. (2018). Exploring ESL teacher beliefs and classroom practices of CLT: A case study. International Journal of Instruction, 11(1), 295-310. https://doi.org/10.12973/iji.2018.11121a

Qarout, D., Pylvainen, R, Dahdah., S \& Palmer, R. (2015). Jordan teachers, survey of Queen Rania foundation. Retrieved 12/2/2019 from https://www.qrf.org/sites/default/files/Jordan\%20Teacher\%20Survey\%20 2015.pdf

Rublik, N. (2017). Language acquisition and cultural mediation: Vygotskian theory. Asia Pacific Journal of Contemporary Education and Communication Technology, 3(1),334- 345.

Smadi, O., \& Linguistics, A. (2015). The Effect of an instructional reading program based on the successful readers' strategies on Jordanian EFL eleventh grade students ' reading comprehension. Journal of Education and Practice, 6(15), 76-88.

Sofiana, N. (2018). Developing cooperative integrated reading and compositionbased role-playing game application as an alternative media in the reading learning. Journal on English as a Foreign Language, 8(2), 170-188. https://doi.org/10.23971 ßefl.v8i2.887

Takallou, F. (2011). The effect of metacognitive strategy instruction on EFL 
learners' reading comprehension performance and metacognitive awareness. Asian EFL Journal, 13(1), 272-300

Talebi, M., \& Marzban, A. (2015). The effect of teaching critical reading strategies on advanced Iranian EFL Learners' vocabulary retention. Theory and Practice in Language Studies, 5(3), 572-580.

\section{Author's Brief CV}

Naima Al-Husban received her Ph.D. in Curriculum and Instruction from the University of Jordan in 2016. In 2001, she worked as an EFL teacher for ten years, and she participated with the British Council to train EFL teachers in Jordan and is currently an assistant professor at Arab Open University. 